\title{
A Reward for Your Toil
}

\author{
Textual Notes on 'Sulpicia' (Epigr. Bob. 37)
}

\author{
T.A.J. Hockings | ORCID: 0000-0001-9728-9514 \\ Magdalen College, University of Oxford, Oxford, UK \\ tajhockings@gmail.com
}

Received January 2021 | Accepted March 2021

The text of 'Sulpicia's' fabella on Domitian's expulsion of philosophers from Rome in 88/89 and 93/94 rests on four direct or indirect copies of a single, highly corrupt manuscript of the late antique anthology known as the Epigrammata Bobiensia. This poem has been of relatively minor scholarly interest due to doubts about its authenticity, ${ }^{2}$ and several passages remain very difficult. A minority maintain a possible Domitianic date, ${ }^{3}$ but the majority date it to the $4^{\text {th }}$ or $5^{\text {th century, }}{ }^{4}$ possibly with a terminus ante quem of c. 400 , when the Bobbio anthology was assembled, and there was a marked resurgence of interest in Sulpicia's poetry. ${ }^{5}$ It has been given a possible date more specifically in the reign of Theodosius I. ${ }^{6}$

1 The majority opinion is that this poem is a late antique forgery. I am using the name only for convenience' sake, without intending to presume the date of composition. Since the date is uncertain, assumptions on the date can prejudice the editor. If the poem is genuine, this is the Sulpicia mentioned by Martial $(10.35,38)$.

2 It is rejected by discussions of Martial's Sulpicia in Merriam 1991, 303-304; Parker 1992, 91-92; and Richlin 1992, 125, 132-134.

3 Butrica 2006 passim; Butler 1909, 178-179.

4 The editors Fuchs 1968, Lana 1949 and Rampioni 1982 all give a late date.

5 See Auson. Cent. Nupt. 139.5-6: Sidon. Carm. 9.261-262): Fulg. Myth. 1.4. Mattiacci 1999 considers Sulpicia's poetics in the light of her reception in Martial, Fulgentius, and vv. 1-11 of this poem.

6 Smolak 2010, 223-224. 
cetera [carmina] quin etiam quondam quae mollia lusi primaque Romanas docui contendere Graiis et salibus variare modos, constanter omitto ${ }^{7}$

7 cetera] ludicra Peiper dub. cetera quin] carminaque latere facile crediderit Butrica quondam quae Heinsius: quod denique $\Omega$ : quot denique ed. Lugdunensis an. 1558. mollia Burmann: millia $\Omega \quad 8$ Romanas Vinetus, Scaliger: Romanos $\Omega \quad 9$ modos Butrica: novis $\Omega$

and the rest in fact that were my tender play, and I was the first [woman] to teach Roman women to vie with Greeks and to vary their measures with wit, I leave off with equanimity

This is one of the most troubled passages in the poem. The gist of the previous verses $\left(5^{-6}\right)$ is that Sulpicia does not want to use the metres she has previously used, but will instead write in hexameters. Butrica punctuates with a comma before cetera, but the presence of the conjunction quin etiam means that it would be much better to punctuate with a full-stop or semi-colon before it, as for instance in Baehrens and the Loeb edition of Ausonius. ${ }^{8}$ Sulpicia's basic thought in vv. 7-9 is cetera quin etiam constanter omitto 'and the rest, indeed, I leave off with equanimity'. The remainder is separate, and should be punctuated as such. The issues in these verses lie in the manifestly corrupt quod denique milia lusi. Quod may be taken adverbially in apposition to cetera and translated as 'everything else, the fact that etc.', but milia lusi introduces nothing new, as vv. 8-9 do, and as the reader expects from cetera. This problem is neatly fixed with Burman's mollia, which introduces elegy, but denique is irrelevant no matter how I try to translate it.

So, against the editors, I argue that quod is acceptable here, whereas the existing conjectures introduce a solecism, after which we would also need to introduce a lacuna after v. 8 , as Butrica originally suggested. ${ }^{9}$ However, Heinsius's quondam replaces the irrelevant denique with something far more

7 Epigr. Bob. 37.7-9. The text, apparatus, and translation are from Butrica 2006, expect that I have used the siglum $\Omega$ instead of $O$ to represent the agreement of the manuscripts. Other translations are my own.

8 Baehrens 1883, 96; Evelyn-White 1921, 282.

9 Butrica 2000 ad loc. 
pointed: 'I once wrote elegies, now let me write hexameters'. This part of his conjecture can stand, and I would therefore print quondam quod mollia lusi. ${ }^{10}$

sed virtus, agitata domi [et] Latialibus armis, $\quad 18$

in freta Sicaniae et Carthaginis exilit arces, $\quad 23$

ceteraque imperia et totum simul abstulit orbem. ${ }^{11} \quad 24$

18 et del. Baehrens $\quad$ Latialibus Butrica: socialibus $\Omega \quad 23$ artes $V$

But courage, trained at home on wars in Latium, jumped to the straits of Sicily and the citadel of Carthage and the other empires as well, and for its prize it took the whole world together.

Here Sulpicia describes the growth of Rome's geo-political power, in a way that either refers to specific historical accounts (Lana adduces Florus 1.18), ${ }^{12}$ or perhaps more likely a common shared narrative of how Romans saw their rise to power. ${ }^{13}$ The transmitted text shows a false distinction between domi and socialibus armis, and an incompetent chronological error in placing the Social Wars before the Punic Wars. So I accept Butrica's text here, but for me there remains a small inelegance, for which there is a small fix. Here armis must mean wars, as it often does, but this is an odd noun to balance domi, freta, arces, imperia, and orbem, all of which describe the place where virtus was trained rather than the means. Armis looks very much like a small slip for arvis, which will restore the balance I expect here.

deinde, velut stadio victor qui solus Achaeo

languet et immota secum virtute fatiscit, sic itidem Romana manus, contendere postquam

destitit et pacem longis frenavit habenis.

ipsa domi leges et Graia inventa retractans

10 If quod is deemed too loose, we may perhaps substitute a causal conjunction that can stand with both clauses in vv. 7-8. Nam quondam gives the necessary sense (quondam could have been corrupted to quod den-, and -ique would then be a metrical interpolation after nam was lost after-etiam), but it is not the only possible reading.

11 Epigr. Bob. 37.18-24.

12 Lana 1949, 45-50.

13 Butrica 2006, 76-77. 
omnia bellorum terra quaesita marique

praemia consilio et molli ratione regebat. ${ }^{14}$

25 studio $\Omega$, corr. ed. Lugdunensis an. $1558 \quad$ lacunam post $v .25$ statuit Fuchs $\quad 26$ immota] confecta coniecit Butrica exempli gratia secum] solus Fuchs: sensim Heinsius: senior Heinsius: senium Lana: demum temptavit Butrica fatiscit Scaliger: facessit $\Omega$ : fatescit Fuchs: senescit Speyer dub. $\quad 28$ lentis Butrica: longis $\Omega$ : longe Fuchs

Then, as the victor who alone faints in the Achaean stadium and collapses with his courage undiminished with himself, just exactly so Rome's gang once they ceased to struggle, and bridled peace with gentle reigns. It was in reviewing at home the laws and the discoveries of the Greeks that they ruled with counsel and soft reason all the prizes of war acquired on land and sea.

Here Sulpicia is comparing Rome's gradual corruption to an exhausted but victorious athlete. There is an interpretive question in whether the simile ends at v. $28^{15}$ or continues to v. 31 . I agree with Butrica in ending it in v. 27 , as vv. 29-31 have no clear point of comparison with the simile, even if we supposed a lacuna after v. 25 (so Fuchs) or more likely v. 26 , which would extend the simile to what happens to the athlete after his victory.

The first major textual problems are in vv. 26-27. Firstly, Butrica asserts the difficulty of qui, which leaves the reader expecting a main verb that is not forthcoming. Fuchs places a lacuna after v. 28, where the comparison would have ended, but I am willing to supply a verb in ellipsis. More compelling is Butrica's point that solus is otiose, as there is obviously only ever one winner, and I would also add that he would hardly be alone in being tired. Solus is so banal that I do not think it can be genuine. I suggest laetus, which of all my attempts is the only one that does not introduce another superfluous epithet. ${ }^{16}$

The next problem is with the phrase immota secum virtute, as secum is barely comprehensible and immota is the opposite of what the sense requires, ${ }^{17}$ assuming that virtus here refers purely to physical strength, which is strongly suggested by the focus on physical rather than mental fatigue. I find Butrica's demum, 'in the end', in place of secum more compelling than he himself thought, but his suggestion of confecta in place of immota is only diagnostic,

\footnotetext{
14 Epigr. Bob. 37.25-31.

15 Baehrens similarly punctuates with a colon after Romana manus.

16 Butrica 2000 had earlier tried fessus as a diagnostic conjecture.

17 See Butrica 2006, 107-108.
} 
so I suggest amota, 'cast off', as a firmer solution. This verb is not uncommonly applied to abstract ideas (e.g. Vulg. 2. Macc. 6:16, Eccl. 11:10 for late examples; Hor. S. 1.1.27 for an early one).

The last issue I wish to address here is longis habenis in v. 28 , where 'long' has no point relevant to the simile. Butrica's lentis (for which he cites Varius 3.1 (ed. Courtney); Ov. Ars 1.5, Met. 15.420, Tr. 4.6.2) is a good conjecture in anticipating molli ratione in v. 31, but I think this can be improved with largis, 'slack' (OLD $1 \mathrm{~b})$, as it is closer to the transmitted longis and equally apt in sense. For this usage, cf. Luc. 7.225; Sil. 7.696, 17.541.

nunc igitur qui rex Romanos imperat inter, 35 non trabe sed tergo prolapsus et ingluvie albus ${ }^{18}$

35 rex Romanos Douza: res romanas $\Omega$ imperat Scaliger, Pithoeus: inferat BVP: inserat $A \quad 36$ tabe $A \quad$ propensus Fuchs $\quad$ et $V P:$ in $B \quad$ albus $V P$ : albas $B$ : auctus tempt. Butrica

so now the man who is ruling as a king among the Romans, a degenerate not with his beam but with his back, and white in the throat

Verse 36 forms an accusation of mollitia against Domitian, but Butrica doubts "that ingluvie albus could mean 'white in the throat,' i.e., from receiving semen, since the semen could not be seen once inside the throat". ${ }^{19}$ I share this, as I would expect to see a word for the mouth, face, or lips in this context (as in Catul. 80), but none will fit here. Butrica, the only critic to offer a conjecture here, suggests auctus, i.e. 'increased by greed', as a reference to Domitian's obesity, but this usage of auctus seems out of place here and et leads me to expect a close relationship between tergo prolapsus and ingluvie albus. I see no reason to doubt that sexual vice is what Sulpicia is talking about. I suggest inluvie albus, 'white with filth'. The term is particularly associated with bodily uncleanliness (e.g. Lucr. 6.1270), so the extension of this usage to the 'pollution' of semen is not unnatural.

Musa velim moneas ...

mene itidem migrare velis vel denique quidvis ut dea quaere aliud tantum Romana Caleno moenia iucundos pariterque averte Sabinos. ${ }^{20}$

\footnotetext{
18 Epigr. Bob. 37-35-36 (immediately following 25-31 in Butrica).

19 Butrica 2006, 109.

$20 \quad$ Epigr. Bob. 59-63.
} 
61 mene Withof: nunc $\Omega \quad$ velis Burmann: velit $\Omega$ : velint ed. Lugdunensis an. 1558: velim Boxhorn $62 \mathrm{ut}]$ tu vel i Heinsius: vel tempt. Butrica $\quad 63$ iucundos BP: facundos V: iucundes Kroll: iucundo tempt. Butrica

Muse I should like you to advise whether you wish me now to emigrate in the very same way or finally whatever as goddess seek something else: only for Calenus Rome's walls pleasant and equally fend off the Sabines.

This is another very difficult and highly corrupted passage, so I have omitted the simile, which I regard as insoluble. Iucundos in v. 63 is clearly wrong, as the Sabines were quite the opposite. Iucundes (Kroll), is a popular remedy, but if this is accepted the resulting expression is still strange. The gist may be paraphrased with Kroll's emendation as 'Muse, would you please advise me if you want me to migrate, or finally you, ${ }^{21}$ goddess, do something else: just make Rome's walls pleasant through Calenus' presence, and at the same time keep the Sabines away'.

Firstly, denique cannot mean 'finally' here unless there is a lacuna after velis. Sulpicia has only suggested one possibility to the Muse before vel denique, so it can hardly serve as a climax to her thoughts. I do not see what could fill a lacuna here, as migration is an extreme solution, so it is preferable to reinterpret vel denique here as 'or at least', as in Hor. Ep. 2.2.127. ${ }^{22}$ Following this, it is apparent that aliud is wrong, as the rhetoric demands that Sulpicia say 'at least do something, whatever it is' rather than 'at least do something else, whatever it is'. Faulty logic is an unattractive defence to me in this case; if denique means 'at least', aliud conceals aliquid.

The paraphrase now runs (again with Kroll's emendation) as 'Muse, would you please advise me if you want me to migrate, or at least do something, goddess, whatever it is: just make Rome's walls pleasant through Calenus' presence, and at the same time keep the Sabines away'. Kroll's reading still makes for an incongruous text, but in this case the faulty logic is defensible as suggesting the speaker's exasperation. As a disjunctive vel is weak, so the clause beginning with tantum should then introduce a proviso for what the Muse advises,

21 I prefer Heinsius' $t u$ to the rather weak $u t$, but it does not affect the paraphrase.
22 The parallel was adduced by Fuchs 1968,46 . 
including if it is migration. But if it is, how pleasurable Rome is to Sulpicia is irrelevant. Deeper corruption, however, is not impossible. ${ }^{23}$

The presence of these Sabines is also potentially a problem. They are renowned for their moral strictness, so the likely sense would be that Sulpicia wishes her Muse to ward off such people from her erotic poetry. It may further be a coded reference to Domitian's perpetual censorship (D.C. 53.18). However, I am not convinced that the Sabines have the necessary status as a byword for the morally censorious type to stand here as a bare generalisation, as for instance Cato can (e.g. Mart. 1 pr.). The generic plural is more suggestive of an individual called Sabinus, but if that is correct his identity is a mystery. Perhaps the text should read severos, Sabinos having suggested itself from Romana in the previous verse.

pone metus caecos, cultrix mea summa. tyranno ecce instant odia, et nostro periturus honori est: ${ }^{24}$

65 caecos Hertz: aequos $\Omega$ : aegros Peiper $\quad$ sic distinxit Butrica: mea. Summa edd. aliae 66 ecce Heinsius: haec $\Omega$ odia] gladii malit Butrica honori Burmann, Fuchs dubitanter: honore $\Omega$

Lay aside your blind fears, my supreme devotee. Over the tyrant, behold, hatred looms, and he is to die to our honour:

This is the beginning of the Muse's response to Sulpicia, and here I will focus on odia. Butrica doubts this word, as it "lacks a concrete reference". ${ }^{25}$ He prefers gladii, with reference to the dolon in Suetonius' account of Domitian's assassination (restored by conjecture in Dom. ${ }_{17}$ ). ${ }^{26}$ While I agree that odia is too vague, gladii seems too specific to complement the unspecific nostro periturus honori. I would prefer something in between these two, and so suggest dira, 'horrors', for odia. If the $r$ had been carelessly omitted, producing dia, odia would have been a reasonable guess to restore sense.

23 As a diagnostic conjecture we may perhaps try delectant for iucundos, taking tantum ... delectant as a parenthetic comment meaning 'Rome's walls only delight because of Calenus'. Fuchs 1968, 46 came to the same interpretation (with a much more radical text). For the idea, cf. Prop. 1.8b.31-32.

24 Epigr. Bob. 37.65-66.

25 Butrica 2006, 116.

26 Dolon might look attractive at first but it will not fit the metre. 
vive, vale. manet hunc pulchrum †tua fama dolorem $\dagger$ :

Musarum spondet chorus et Romanus Apollo. ${ }^{27}$

69 sua Pithoeus

Live, fare well. Your reputation awaits this catamite pain:

The chorus of Muses pledges it, and Roman Apollo.

The final lines are some of the most difficult of the poem. It ends with the Muses' response to Sulpicia's demands, and they reply with a prediction of Domitian's death (vv. 65-66, discussed above) and some other kind of promise here. Normally Pithoeus' sua is read, and the second promise is also connected to Domitian, but this solves nothing, as pulchrum dolorem is meaningless to me however I may try to translate it. ${ }^{28}$

The Muses have already foretold Domitian's death, and any other promise about Domitian's fate other than the tortures of the underworld will be an anti-climax here, which cannot be introduced unless the ending is totally rewritten. The manuscripts' tua is therefore secure, and the promise should be one for Sulpicia. As this must be a kind promise, pulchrum is also secure in its usual meaning, and the corruption is to be isolated to dolorem. Apollo and the Muses, then, say 'your (i.e. favourable) reputation awaits this beautiful †pain $\dagger$ '. For pain, I suggest laborem, 'effort'. As I see it this a promise that Sulpicia's poetry will be famous, and a very appropriate one to be given by Apollo and the Muses. ${ }^{29}$ The error is due to a synonym substitution, for which cf. Ov. Met. 9.289, where $M$ reads dolores for labores.

The phrase pulcher labor is striking, but not difficult. I have found it in two other places in Classical literature: ${ }^{30}$ hunc favor aequus | provehit et pulchro reddit sua dona labori ('Even-handed favour promotes him and gives him his gifts for his beautiful efforts', Juv. 16.56-57), and digestaque praeda ... | cetera bellantum dextrae pulchroque labori ('The booty is distributed ... The rest was for the warrior's strength and beautiful efforts', Sil. 15.264-267). The parallel in Juvenal is particularly interesting. If laborem is correct both passages use this term in the same metrical sedes, forming a sandwich around the subject, tua

27 Epigr. Bob. 37.69-70.

28 Fuchs 1968, 37 n. 19 suggests that pulcher here is equivalent exoletus.

29 The anonymous reviewer reads this as taking up the poem's theme of fame and fortune.

$30 \quad$ That is to say according to the PHI disk, supplemented with a search of the poetic works of Ausonius, Prudentius, Claudian, and Sidonius Apollinaris, given the poem's possible dates. 
fama in Sulpicia and sua dona in Juvenal. ${ }^{31}$ The context in all three is describing rewards for people's efforts, but in Sulpicia the efforts are poetic, while in Juvenal and Silius they are military. The similarities in Sulpicia and Juvenal are surely not accidental: one is imitating the other, so this is a new piece of evidence to be considered for establishing the poem's date. Indeed, the balance of evidence may even favour Sulpicia's priority. In deciding which of two passages has priority there is a tendency for the original to be more organically embedded in its context, and for the imitation to expand and elaborate on the original. Sulpicia's pulcher labor describes her entire poem, and pulcher has an obvious point in complimenting the poet's skill. In Juvenal, however, pulchro is ironic, and there are no details for what the soldier's pulcher labor is. In the second case, Juvenal's phrase is expanded so that the 'rewards' include military promotion as well as booty. On the other hand, these tendencies are not conclusive, and the most commonly accepted date for composition (c. 40o), saw a great revival in Juvenal's popularity, ${ }^{32}$ so it may well be expected for a poet of that period to know and refer to him.

\section{Bibliography}

Baehrens, E. (1883). Poetae Latini Minores, Vol. 5. Lipsiae.

Butler, H.E. (1909). Post-Augustan Poetry. From Seneca toJuvenal. Oxford.

Butrica, J.L. (2000). Sulpicia Conquestio. Epigrammata Bobiensia 37 AP. http://www .curculio.org/Sulpiciae/Conquestio.html (ed. Hendry, M., accessed 7/o1/2021).

Butrica, J.L. (2006). The Fabella of Sulpicia (Epigrammata Bobiensia 37). Phoenix 6o, pp. 70-121.

Evelyn-White, H.G. (1921). Ausonius with an English Translation, Vol. 2. Oxford.

Fuchs, H. (1968). Das Klagelied der Sulpicia über die Gewaltherrschaft des Kaisers Domitian. In: M. Sieber, ed., Discordia concors. Festgabe für Edgar Bonjour zu seinem siebzigsten Geburtstag am 21. August 1968, Vol. 2, Stuttgart, pp. 32-47.

Giordano Rampioni, M. (1982). Sulpiciae Conquestio (Ep. Bob. 37). Bologna.

Lana, I. (1949). La Satira di Sulpicia. Studio critico, testo e traduzione. Torino.

Mattiacci, S. (1999). Castos docet et pios amores, lusus, delicias facetiasque, ovvero la poesia d'amore secondo l'altra' Sulpicia. Invigilata Lucernis 21, pp. 215-241.

Merriam, C.U. (1991). The Other Sulpicia. CW 84, pp. 303-305.

31 Perhaps Juvenal even wrote reddit pulchro, which would then put pulchro in the same sedes in both passages.

32

R.J. Tarrant ap. Reynolds 1983, 200. 
Parker, H. (1992). Other Remarks on the Other Sulpicia. CW 86, pp. 89-95.

Reynolds, L.D. (1983). Texts and Transmissions. A Survey of the Latin Classics. Oxford. Richlin, A. (1992). Sulpicia the Satirist. CW 86, pp. 125-140.

Smolak, K. (2010). Three Latin Paratexts from Late Antiquity and the Early Middle Ages ('Sulpicia', 'Seneca'-'Paulus', Carmen Navale). In: P.S. Alexander, A. Lange, and R.J. Pillinger, eds., In the Second Degree. Paratextual Literature in Ancient Near Eastern and Ancient Mediterranean Culture and Its Reflections in Medieval Literature, Leiden, pp. 219-237. 